\title{
Alimentação, Agrotóxicos e Saúde
}

Mesmo com as delimitações e especificidades temáticas e de abordagem metodológica observadas na organização de um evento científico, o Congresso Mundial de Nutrição (World Nutrition, Rio 2012) assumiu, de fato, as características de uma reunião de cúpula que, extrapolando as restrições de um encontro internacional de estudiosos, estendeu-se ao espaço aberto e universal das questões de cidadania. Ou seja, ao campo dos direitos e deveres que deve mobilizar o estado democrático, a sociedade civil e as representações corporativas, na identificação, discussão de alternativas e controle social/comunitário dos problemas humanos.

No âmbito destas considerações convém destacar um documento que deve se tornar histórico: o chamado "Dossiê Abrasco" sobre agrotóxicos no Brasil.1 De fato, mais do que um manifesto acadêmico ou corporativista, deve ser entendido, divulgado e, sobretudo, apoiado como um movimento de ideias a respeito de um dos problemas mais cruciais de nosso tempo: os impactos dos agrotóxicos na saúde. É uma tomada de posição oportuna e necessária, pelos efeitos nocivos já evidenciados e dos riscos potenciais crescentes que se prenunciam pelo uso dos chamados defensivos agrícolas no Brasil. Só como forma de ingressar no assunto: a) somos os campeões mundiais no uso de biocidas agrícolas; b) dos 50 agrotóxicos mais utilizados nas lavouras de nosso país, 22 são proibidos na União Européia, inclusive em nações onde se acham as matrizes externas de suas empresas produtoras. Mais do que um paradoxo, é um dolo que não pode ser tolerado.

Historicamente, os agrotóxicos tiveram um papel notável no aumento da produção agropecuária, integrando os quatro pilares estratégicos da Revolução Verde proposta por Norman Borlaug2 para a rápida expansão da produção de grãos (leguminosas e cereais) no mundo, sobretudo a partir das décadas de 1960 e 1970, seguindose dos itens referentes a frutas, verduras e pastagens cultivadas. No entanto, cinco décadas após, as evidências acumuladas, seja no campo específico da produção agropecuária, seja principalmente no setor saúde e meio ambiente, conduziram a uma revisão crítica de sua efetiva validade. Mais e mais agrotóxicos, novas e novas gerações de defensivos levaram à conclusão de que se tratava de um túnel sem iluminação de percurso e de saída. O próprio Norman Borlaug, ganhador do prêmio Nobel da Paz pela formulação de sua estratégia, reconheceu a falha de alguns pressupostos, como a mecanização indiscriminada das terras cultivadas e a contaminação dos solos e dos produtos agropecuários. A "Primavera Silenciosa", de Carson, 3 também ganhadora do Prêmio Nobel, acendeu o sinal amarelo para a presidência da República nos Estados Unidos, que era (como ainda é) o maior país exportador de alimentos do mundo. Na época, o presidente John Kennedy criou um grupo para estabelecer medidas de acompanhamento e controle para a produção, comercialização e utilização de agrotóxicos no país. Os Estados Unidos aplicavam, então, cerca de um quilo e meio desses produtos por hectare e caminhavam para a marca de dois quilos.

Hoje no Brasil se usa não dois quilos de defensivos agrícolas por hectare, mas quase cinco quilos por cada habitante! E estamos ainda, permissivamente, com o sinal verde aberto, detendo o título nada recomendável de campeão mundial no uso de venenos na agricultura, contaminando águas continentais e oceânicas, solos e plantas, animais terrestres e aquáticos e pessoas de todas as idades com os efeitos nocivos de seu manejo, inalação e ingestão. É um risco que se massificou ou, mais que isto, se universalizou. Em nosso país, todos nós, todos os dias, em praticamente todas as refeições, ingerimos um pouco de agrotóxico, como se fosse um condimento natural da culinária nacional. Até o leite materno, o mais natural, mais puro e mais completo dos alimentos para as fases iniciais da vida extra-uterina, torna-se, agora, veículo de biocidas produzidos pelas fábricas de insumos agrícolas. Os dados são impressionantes. Assim, segundo a Agência Nacional de Vigilância Sanitária, ${ }^{1}$ na safra de 2010/2011, a venda de agrotóxicos no Brasil movimentou 936 mil toneladas, gastando 7,3 bilhões de dólares, o que corresponde a quase $20 \%$ de todo o gasto mundial, deixando em segundo lugar os Estados Unidos, com uma participação de 17\% no mercado global. Nos 71 milhões de hectares cultivados com lavouras permanentes ou temporárias no território nacional, são pulverizados 12 litros por hectare com exposição média 
ambiental/ocupacional/alimentar de 4,5 litros por habitante. ${ }^{1}$ No entanto, por diferentes razões, são as mulheres e as crianças, notadamente no período gestação/lactação que mais se expõem aos perigos desses venenos, impropriamente chamados de defensivos.

Mantidas as tendências atuais, a situação deve se agravar ainda mais nos próximos dez anos. Espera-se que a produção de commodities, representada sobretudo por monoculturas químico-dependentes, deva aumentar em $55 \%$ para a soja, $56 \%$ para o milho, $45 \%$ para o açúcar, $50 \%$ para o leite e em torno de $30 \%$ para os três principais tipos de carne: bovina, suína e carne de frango, que usam maciçamente soja e milho em suas rações.

Diante desse cenário, cabe a pergunta crucial: quais as implicações para a saúde?

Pondo de lado os efeitos agudos, mais visíveis e mais raros, há uma variedade de consequências crônicas menos perceptíveis e, portanto, mais perigosas. Sem detalhar aqui a especificidade dos produtos (inseticidas, fungicidas e herbicidas), o documento da Associação Brasileira de Pós-Graduação em Saúde Coletiva (ABRASCO) menciona como manifestações de intoxicação crônica: efeitos neurotóxicos retardados, alterações cromossomiais, lesões hepáticas e renais, neuropatias periféricas, disfunções cardíacas, dermatites de contato, asma brônquica, Doença de Parkinson, teratogêneses, diversos tipos de câncer, fibrose pulmonar, hipersensibilidade, deixando em aberto a relação de outras consequências menos comuns ou menos estudadas. Estas referências fazem parte de um documento da Organização Pan-Americana da Saúde/Organização Mundial da Saúde (OPAS/OMS) já defasado em 16 anos. ${ }^{4}$ Se devidamente atualizada, a lista sem dúvida seria bem mais extensa.

A propósito da saúde materno-infantil, há um livro que já se tornou um clássico: "O Camponês e a Parteira", de Michael Odent. 5 Traduzido em várias línguas e reproduzido em diversas edições, trata de uma analogia temática, conceitual e alegórica entre a industrialização do parto, com a massificação das cesarianas e a industrialização da moderna agricultura e da pecuária, mediante sucessivas inovações tecnológicas, entre as quais se ressalta a demanda crescente e diversificada dos agrotóxicos. A agropecuária massificada em ecossistemas particulares, como na Região dos Lagos, na América do Norte, represas da Holanda e do Japão, implicando na acumulação progressiva de agrotóxicos em suas águas, resultou em observações controladas em graves consequências para a saúde das crianças, por conta da contaminação do organismo de suas mães durante a gestação. ${ }^{5}$ Em avaliações decenais, a partir de 1966, verificou-se que a razão de óbitos fetais masculinos em comparação com fetos femininos no Japão aumentou, sucessivamente de 2,50 para 3,10 (1976), 6,19 (1986) e finalmente, 10,01 vezes, em 1996. Portanto, quatro vezes mais, dentro de três décadas. A correlação ecológica se estabelece com a concentração de agrotóxicos nas águas, nas terras adjacentes e nos alimentos (peixes e lavouras) dessas localidades. Mas, ao mesmo tempo e na mesma proporção, aumentaram as anomalias congênitas nos fetos machos: hipospádia e encarceramento abdominal das gônadas masculinas. Demonstrou-se, ainda, diferenças bem significativas na ocorrência de déficit de desenvolvimento mental nas crianças. Odent 5 chega a antever que o agravamento da situação, ao ritmo em que está ocorrendo, poderia, no futuro, resultar na necessidade de que, antes da concepção, as mulheres tenham de se submeter a um processo de desintoxicação de seus depósitos de agrotóxicos acumulados no organismo para reduzir as graves consequências para seus conceptos. Seria uma fase inteiramente nova da assistência pré-natal. Ou melhor, pré-concepcional.

$\mathrm{Na}$ verdade, é uma situação ameaçadora, justificando a pertinência e oportunidade do Dossiê da ABRASCO, divulgado e acolhido por unanimidade pelos participantes no Congresso Mundial de Nutrição como um alerta à sociedade e ao Estado Brasileiro.

\section{Malaquias Batista Filho 1 \\ Mariana Navarro Tavares de Melo 2}

1,2 Instituto de Medicina Integral Prof. Fernando Figueira (IMIP). 


\section{Referências}

1. Carneiro FF, Pignati W, Rigotto RM, Augusto LGS, Rizollo A, Muller NM, Alexandre VP, Friedrich K, Mello MSC. Dossiê ABRASCO: um alerta sobre os impactos dos agrotóxicos na saúde. Rio de Janeiro: ABRASCO; 2012. $1^{\text {a }}$ Parte. 98 p.

2. Borlaug NE. Feeding a human population that increasing crowds a fragile planet. Acapulco, MX: International Society of Soil Science; 1994. 15 p.

3. Carson RL. Silent Spring. Greenwhich: Fawcett; 1962.

4. OPAS (Organização Pan-Americana da Saúde). Ministério da Saúde do Brasil. Secretaria de Vigilância Sanitária. Manual de Vigilância de populações expostas a agrotóxicos. Brasília, DF; 1996.

5. Odent M. O Camponês e a Parteira: uma alternativa à industrialização da agricultura e do parto. São Paulo: Ground; 2003.189 p. 